\title{
Serum oestradiol, progesterone, chorionic gonadotrophin and prolactin concentrations during pregnancy in the Bolivian squirrel monkey (Saimiri sciureus)*
}

\author{
E. J. Diamond, S. Aksel, J. M. Hazelton, R. H. Wiebe and C. R. Abee $\dagger$ \\ Department of Obstetrics and Gynecology, Division of Reproductive Endocrinology, and \\ $\dagger$ Department of Comparative Medicine, University of South Alabama, Mobile, Alabama 36688, \\ U.S.A.
}

\begin{abstract}
Summary. Concentrations of chorionic gonadotrophin gradually increased during early pregnancy, reached maximum values at mid-gestation, then declined to low levels. Oestradiol- $17 \beta$ concentrations were relatively low $(300-600 \mathrm{pg} / \mathrm{ml})$ during early pregnancy, increased thereafter to high levels $(10-35 \mathrm{ng} / \mathrm{ml})$, and then appeared to decline towards term. Concentrations of progesterone were constant $(100-200 \mathrm{ng} / \mathrm{ml})$ for the first 15 weeks of gestation, suggesting that sequential measurements of progesterone could be used to diagnose early pregnancy. Prolactin concentrations rose during pregnancy, reaching maximum values at term.
\end{abstract}

\section{Introduction}

Reproduction in the squirrel monkey is seasonal and in the northern hemisphere breeding occurs from December to March and most animals give birth in June, July and August. The length of the gestation period in captive squirrel monkeys has been estimated using external palpation, bioassay and timed matings and is reported to range from 141 to 162 days (Nathan et al., 1966; Kerber et al., 1977; Stolzenberg et al., 1979). It is not currently known how chorionic gonadotrophin (CG), oestradiol, progesterone and prolactin concentrations fluctuate during pregnancy in this species. To understand better the factors involved in the endocrine regulation of gestation in the squirrel monkey, measurements of the circulating concentrations of these hormones during pregnancy are essential.

\section{Materials and Methods}

Animals. Female Bolivian squirrel monkeys (Saimiri sciureus) were housed in breeding groups with males. The sexually mature animals were exposed to $15 \mathrm{~h}$ light and $9 \mathrm{~h}$ darkness. High-protein monkey chow (Ralston Purina) and water were supplied ad libitum. Animals were given a sucrose-electrolyte solution with vitamin supplement daily in the afternoon.

Two experimental groups were studied. Group A consisted of 10 female squirrel monkeys that were initially selected from stable breeding groups and sampled daily for periods of 19-20 days during the breeding season (December to the end of March). These animals were part of a much larger study to characterize reproductive cyclicity (Diamond et al., 1984) and were selected for this study because they became pregnant. Group B consisted of 5 mature female monkeys that became pregnant and later gave birth to live young. These animals were part of a group of 14 monkeys and differed from Group $A$ in that they were sampled at 14-30-day intervals during the last part of the breeding season and during the early birth season (February to June).

The approximate date of conception and the stage of pregnancy were estimated for each monkey by assuming the length of gestation to be about 150 days (Kerber et al., 1977; Dukelow, 1983) and counting back from the date of birth.

To compare gonadotrophin concentrations in non-pregnant monkeys with those in pregnant animals, random multiple blood samples were also obtained from non-pregnant cyclic and non-cyclic squirrel monkeys.

${ }^{*}$ Reprint requests to Dr C. R. Abee. 
Collection of blood samples. For blood sampling animals were lightly anaesthetized with an intramuscular injection of ketamine hydrochloride (Ketaset: Bristol Laboratories, Syracuse, NY) at a dosage of $15 \mathrm{mg} / \mathrm{kg}$ body weight and $1.0 \mathrm{ml}$ blood was removed by femoral venepuncture. This sampling procedure was completed in less than $5 \mathrm{~min}$. Blood samples were stored overnight at $4^{\circ} \mathrm{C}$, centrifuged the next day and serum stored frozen until assayed. Animals remained in good health throughout the sampling period.

Radioimmunoassay of squirrel monkey CG. Squirrel monkey CG concentrations were measured by a heterologous double-antibody radioimmunoassay technique. All laboratory chemicals were A.C.S. certified and obtained from Fisher Scientific Company (Fairlawn, NJ). Carrier-free sodium iodide was obtained from Amersham (Arlington Heights, IL). Fetal calf serum was obtained from GIBCO (Grand Island, NY) and second antibody (sheep anti-rabbit gamma globulin) from Bostwich Valley South (Hillsborough, NC). Rabbit antiserum (H-26) to the beta-subunit of sheep LH which has been shown to cross-react with CGs from many primate species (Hodgen et al., 1978) was generously supplied by Dr G. D. Hodgen (Reproduction Research Branch, National Institutes of Health). Use of this reagent has been previously described (Hodgen et al., 1974). Radioactive CG was prepared from a highly purified preparation of human CG (CT 119) supplied by the NIADDK of the National Institute of Child Health and Human Development. This preparation was iodinated using minor modifications of the chloramine $\mathrm{T}$ method originally described by Greenwood \& Hunter (1963). The reference preparation (mCG-HRP-2), also obtained from Dr G. D. Hodgen, was a partly purified fraction obtained from macaque urine collected from the 18 th to the 25 th day of gestation (Hodgen et al., 1974). The material used in the present study had a biological activity of $0 \cdot 38 \mathrm{i} . \mathrm{u} . / \mathrm{mg}$ protein. Replicate doses ranging from 5 to $200 \mu \mathrm{g}$ protein were used to construct the dose-response curve. Squirrel monkey $\mathrm{CG}$ concentrations were expressed as $\mu \mathrm{g}$ protein per $\mathrm{ml}$ serum (Hodgen et $a l ., 1974$ ).

The incubation mixture consisted of squirrel monkey serum or reference preparation, antiserum (1:32000 final dilution), buffer and iodinated hCG. Fetal calf serum was added to the standard curve tubes to obviate any nonspecific protein effect (Hodgen et al., 1974). The assay tubes were incubated for $2 \mathrm{~h}$ at $37^{\circ} \mathrm{C}$ followed by an additional incubation of $12-16 \mathrm{~h}$ at $4^{\circ} \mathrm{C}$. After addition of second antibody (sheep anti-rabbit gamma globulin), the assay tubes were incubated for an additional $6 \mathrm{~h}$. The antibody-bound fraction was separated by centrifugation at $1250 \mathrm{~g}$ for 30 min and radioactivity was counted in a Beckman 8500 Gamma Counter (Beckman Instruments, Fullerton, CA) at $2 \%$ error. The final results were calculated using a log-logit transformation on a table top programmable calculator. Recovery was over $85 \%$ when known amounts of reference preparation were added to squirrel monkey serum. High and low control samples were prepared by adding known amounts of hCG to normal human male plasma. Interassay coefficients of variation were determined by including these high and low samples in each assay and were $13.0 \%$ for the high $(n=9)$ and $6.8 \%$ low $(n=12)$ control samples. Intra-assay coefficients were $9 \cdot 0 \%(n=11)$ for high control and $9 \cdot 1 \%(n=13)$ for the low control. The sensitivity of the assay was $25 \mu \mathrm{g}$ protein $/ \mathrm{ml}$.

Oestradiol-17\%. A well characterized and highly specific antibody to oestradiol-17ß was used in these studies and was generously supplied by Dr D. C. Collins and Dr K. Wright (Emory University School of Medicine, Atlanta, GA). Specificity data for this antiserum have been previously reported. No significant cross-reactivity was found with oestrone or oestriol (Wright et al., 1973, 1978). $\left[1,2-{ }^{3} \mathrm{H}\right]$ Progesterone and $\left[2,4,6,7-{ }^{3} \mathrm{H}\right]$ oestradiol-17 $\beta$ were purchased from New England Nuclear (Boston, MA). Oestradiol-17 $\beta$ was measured in ether extracts of squirrel monkey serum. After incubation for $1 \mathrm{~h}$ at $4{ }^{\circ} \mathrm{C}$ with antiserum and $\left[{ }^{3} \mathrm{H}\right]$ oestradiol-17 $\beta$ the separation of bound from free steroid was carried out with dextran-coated charcoal and the radioactivity in the bound fraction was determined in a Beckman LS7500 Liquid Scintillation Counter (Beckman Instruments, Fullerton, CA).

Pools of squirrel monkey serum were shown to parallel the standard curve which ranged from 2.5 to $500 \mathrm{pg} / \mathrm{tube}$. Steroid-free $250 \mu \mathrm{l}$ plasma blanks prepared by the method of Carter (1978) were $<2 \mathrm{pg} / \mathrm{tube}$. Extraction losses were determined for each sample by the addition of 1000 c.p.m. $\left[{ }^{3} \mathrm{H}\right]$ oestradiol to each assay tube. The mean percentage of recovery ( \pm s.d.) was $86.5 \pm 10.5 \%(n=100)$. Assay sensitivity, defined as the mean concentration ( \pm s.d.) of oestradiol needed to decrease the binding of $\left[{ }^{3} \mathrm{H}\right]$ oestradiol to $90 \%$, was $2.3 \pm 0.6 \mathrm{pg}(n=25)$ per tube. This was equivalent to $23 \mathrm{pg} / \mathrm{ml}$. Interassay coefficients of variation were determined by including high and low control samples in each assay and varied between $7.8 \%$ and $15 \%(n=10)$. Intra-assay coefficients were obtained by assaying $10-15$ aliquants of high and low pools of squirrel monkey serum and were $8 \%(n=15)$ and $6 \%(n=10)$ respectively (Diamond $e t$ al., 1984).

Progesterone. Antiserum for progesterone assay was a generous gift from Dr V. Mahesh (Medical College of Georgia, Augusta, GA). Specificity studies showed $0.5 \%$ (progesterone $=100 \%$ ) or less cross-reactivity with the major corticosteroids, androgens, their metabolites, and metabolites of progesterone. Slight cross-reactions were observed with pregnenolone $(1 \cdot 56 \%), 17 \beta$-hydroxyprogesterone $(1.04 \%)$, and deoxycorticosterone $(0.95 \%)$.

Progesterone was measured in petroleum ether extracts of serum. Extracted samples were incubated with antibody and $\left[{ }^{3} \mathrm{H}\right]$ progesterone for $2 \mathrm{~h}$ at $37^{\circ} \mathrm{C}$ followed by overnight incubation at $4^{\circ} \mathrm{C}$. After separation from the free hormone the radioactivity in the bound fraction was determined. Pools of squirrel monkey serum paralleled the standard curve which ranged from 10 to $2500 \mathrm{pg} /$ tube and steroid-free plasma blanks were $<10 \mathrm{pg} /$ tube. Extraction losses were corrected for and assay sensitivity was determined as described above for oestradiol. The mean percentage of recovery ( \pm s.d.) was $82.9 \pm 7.9(n=100)$ and the assay sensitivity, expressed as the mean of the concentration \pm s.d. was $14 \pm 3.2 \mathrm{pg} /$ tube, which was equivalent to $140 \mathrm{pg} / \mathrm{ml}$. Interassay coefficients of variation ranged from 8 to $14 \%(n=10)$ and intra-assay coefficients were $6.0 \%(n=9)$ for a low monkey serum pool and $12 \cdot 1 \%$ $(n=8)$ for a high pool (Diamond et al., 1984). 
Prolactin. Serum concentrations were measured using an homologous double-antibody radioimmunoassay procedure developed for human prolactin. Since purified squirrel monkey prolactin is not available, human prolactin preparations obtained from the National Institute of Arthritis, Metabolism and Digestive Diseases (NIAMDD) were used. Human prolactin reference preparation (AFP-2312C), antiserum (AFP-C11580) and purified human prolactin (AFP-2284C2) for iodination were used.

The hormone was enzymically iodinated using modifications of the lactoperoxidase method (Thorell \& Johansson, 1971). Briefly, lactoperoxidase (Cal Biochem-Behring, San Diego, CA), $1 \mathrm{mCi} \mathrm{Na}^{125}$ I (Amersham Corp., Arlington Heights, IL), and human prolactin $(5 \mu \mathrm{g})$ were combined and the reaction was initiated and carried out by two additions of hydrogen peroxide, each followed by a 45 -sec reaction period. The iodinated hormone was purified using Sephadex G-100 (Pharmacia Fine Chemicals, Piscataway, NJ) column chromatography. The range of specific activities obtained was $35-70 \mu \mathrm{Ci} / \mu \mathrm{g}$ prolactin.

Reagents and unknowns were added to the assay tubes in an ice bath $\left(4^{\circ} \mathrm{C}\right.$ and, after addition of antibody (final dilution $=1: 400000$ ), the assay tubes were incubated for $12-16 \mathrm{~h}$ at room temperature. Bound hormone was separated from free by incubation with sheep anti-rabbit gamma globulin followed by centrifugation. Radioactive bound hormone was counted in a Beckman 8500 Gamma Counter. Since purified squirrel monkey prolactin was not available, our values are expressed as ng human prolactin-like activity $/ \mathrm{ml}$. A pool of squirrel monkey serum was shown to parallel the standard curve. Recoveries of prolactin standard from squirrel monkey serum ranged from 82 to $95 \%$. Interassay coefficients of variation were $6.2 \%(n=12)$ for a high control sample and $14 \cdot 3 \%(n=11)$ for a low control. Intra-assay variability was $6 \cdot 3 \%(n=9)$. The lowest concentration of prolactin that could be detected in this assay was $5 \mathrm{ng} / \mathrm{ml}$. Statistical analyses were carried out using the paired $t$ test and one-way analysis of variance.

\section{Results}

The heterologous radioimmunoassay used in the present study measures circulating concentrations of CG in pregnant squirrel monkeys (Table 1). Although there was some overlap, the hormone concentrations in pregnant animals were 4-fold higher than those in cyclic animals $(P<0.001)$, showing that the squirrel monkey $C G$ radioimmunoassay can distinguish between pregnant and non-pregnant animals in a breeding colony.

Table 1. Serum concentrations of chorionic gonadotrophin in squirrel monkeys

\begin{tabular}{|c|c|c|c|}
\hline & \multirow{2}{*}{$\begin{array}{l}\text { No. of } \\
\text { samples }\end{array}$} & \multicolumn{2}{|c|}{$\mathrm{CG}(\mu \mathrm{g}$ protein $/ \mathrm{ml})$} \\
\hline & & Range & Mean $( \pm$ s.e.m. $)$ \\
\hline Noncyclic & 76 & $25-181$ & $39 \pm$ \\
\hline Cyclict & 117 & $31-354$ & $160 \pm 20$ \\
\hline Pregnant & 135 & $201-1964$ & $699 \pm 201^{*}$ \\
\hline
\end{tabular}



Hormonal patterns for some representative pregnant animals are shown in Figs 1 and 2. Figure 1 shows hormone measurements for $\mathrm{CG}$, oestradiol and progesterone for animals sampled over a 19-20-day period during early pregnancy (Group A). The concentrations of the 3 hormones were elevated, showed daily fluctuations and individual differences.

Figure 1(c) shows a very early pregnancy ( $<25$ days). It has been reported that squirrel monkey CG is detectable only from about Day 25 of gestation to Day 80 (Hodgen, 1980). Based on this information, the start of the sampling period for the monkey depicted in Fig. 1(c) was estimated to be less than 25 days of gestation. During the first 12-14 days of the sampling period, the squirrel monkey $\mathrm{CG}$ concentrations were similar to those measured in non-cyclic and cyclic squirrel monkeys. It was only after Days 12-14 of the sampling period that the levels increased rapidly and 

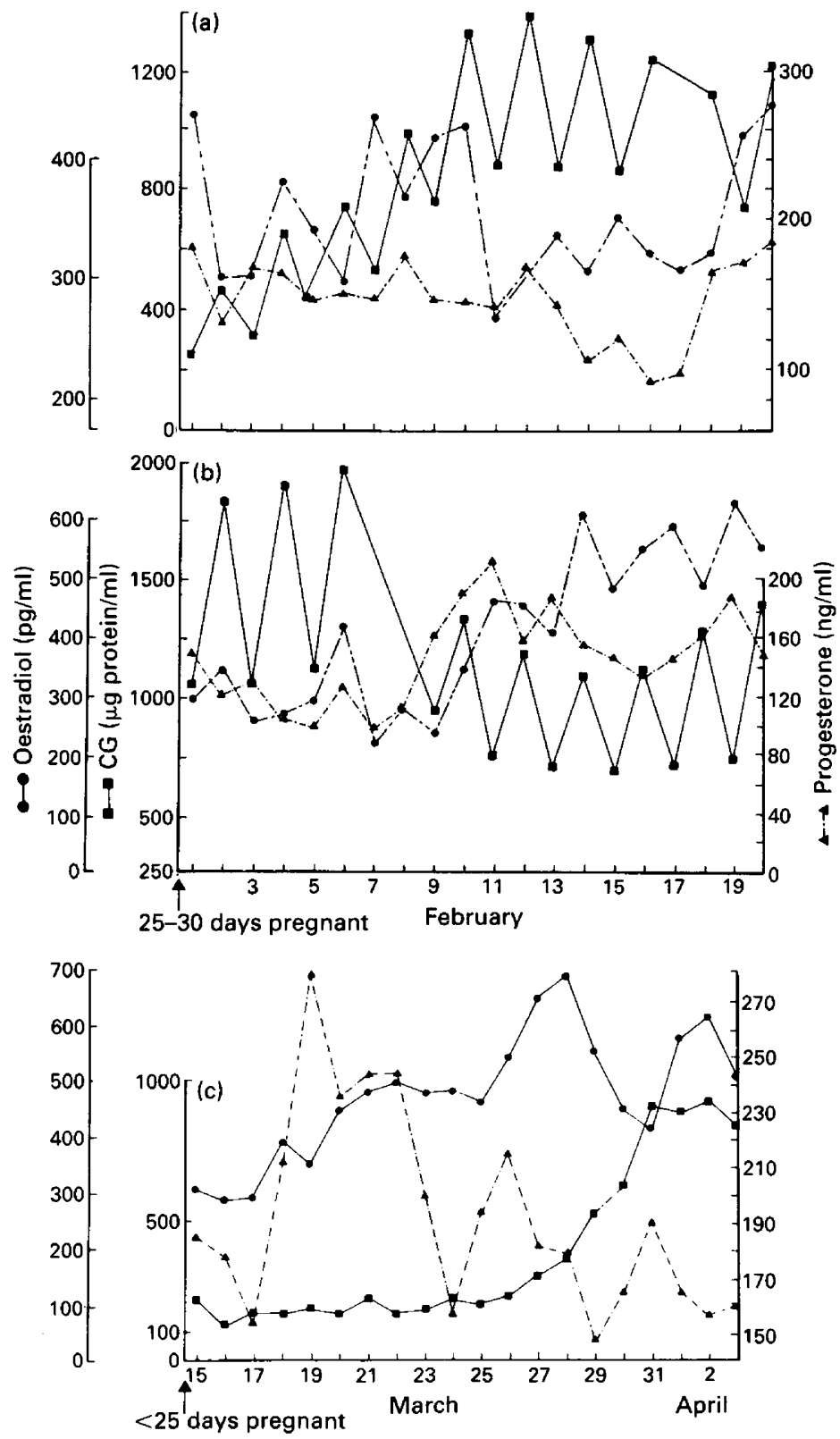

Fig. 1. Daily serum concentrations of oestradiol $(\Theta, \mathrm{pg} / \mathrm{ml})$, progesterone $(\boldsymbol{\Delta}, \mathrm{ng} / \mathrm{ml})$ and chorionic gonadotrophin $(\boldsymbol{\sigma}, \mu \mathrm{g}$ protein $/ \mathrm{ml})$ in squirrel monkeys $25-30$ days pregnant at the start of sampling from 1 to 20 February $(a, b)$ and in one monkey $<25$ days pregnant sampled from 15 March to 3 April (c).

entered the range that is diagnostic for pregnancy (see Table 1). No live birth was reported for this animal nor was any aborted material found.

In Group A, animals that were $<25$ days pregnant, CG concentrations were $100-300 \mu \mathrm{g}$ protein $/ \mathrm{ml}$ and gradually increased to $>900 \mu \mathrm{g} / \mathrm{ml}$. After about 30 days of pregnancy, concentrations increased and fluctuated between 700 and $2000 \mu \mathrm{g} / \mathrm{ml}$. Pregnant monkeys had fluctuating 




Fig. 2. Circulating serum concentrations of chorionic gonadotrophin ( $\mathbf{a})$, oestradiol $(\boldsymbol{O})$, and progesterone $(\boldsymbol{\Delta})$ in squirrel monkeys sampled during a pregnancy which resulted in a live birth $(\mathrm{a}, \mathrm{b})$.

concentrations of oestradiol above $300 \mathrm{pg} / \mathrm{ml}$ and progesterone above $100 \mathrm{ng} / \mathrm{ml}$. Of the $10 \mathrm{preg}$ nant animals comprising Group A, 4 had live births and 2 had confirmed abortions. No live births were observed or aborted material found for the remaining animals in this group. These pregnancies may have resulted in abortions or stillbirths and the fetal material consumed during the night by the other cagemates.

Figure 2 depicts circulating concentrations of CG, oestradiol and progesterone for two representative pregnant squirrel monkeys sampled at 14-30-day intervals during the course of gestation (Group B). The 5 pregnant animals in this group had an increase in CG concentrations during early pregnancy, reaching a maximum between 4 and 11 weeks and then slowly declining and reaching low levels towards the end of pregnancy. CG concentrations reached a maximum during Week 4, remained elevated until Week 6 and decreased to non-pregnant values (cyclic levels, see Table 1) thereafter. The animal depicted in Fig. 2(b) showed a similar pattern, but with maximum CG levels attained during Week 7. Both animals had elevated concentrations of oestradiol during the first third of pregnancy, but $<1.0 \mathrm{ng} / \mathrm{ml}$, followed by a rapid increase occurring at Week 6 or 7 , to high concentrations (over $20 \mathrm{ng} / \mathrm{ml}$ ) during the last third. This pattern of oestradiol secretion was essentially the same for all 5 members of Group B (data not shown). The range of values for oestradiol during the last third of pregnancy was $9-38 \mathrm{ng} / \mathrm{ml}(n=5)$ with most values $>11 \mathrm{ng} / \mathrm{ml}$. Serum progesterone concentrations remained fairly constant during most of the gestation period (Figs 2a, $2 \mathrm{~b}$ ), with rapid declines before birth. The range of progesterone values for the 5 animals studied over the entire gestation period was $80-370 \mathrm{ng} / \mathrm{ml}(n=35)$. Of the progesterone values observed during pregnancy, $96 \%$ were greater than $100 \mathrm{ng} / \mathrm{ml}$, with most between 100 and $200 \mathrm{ng} / \mathrm{ml}$. 


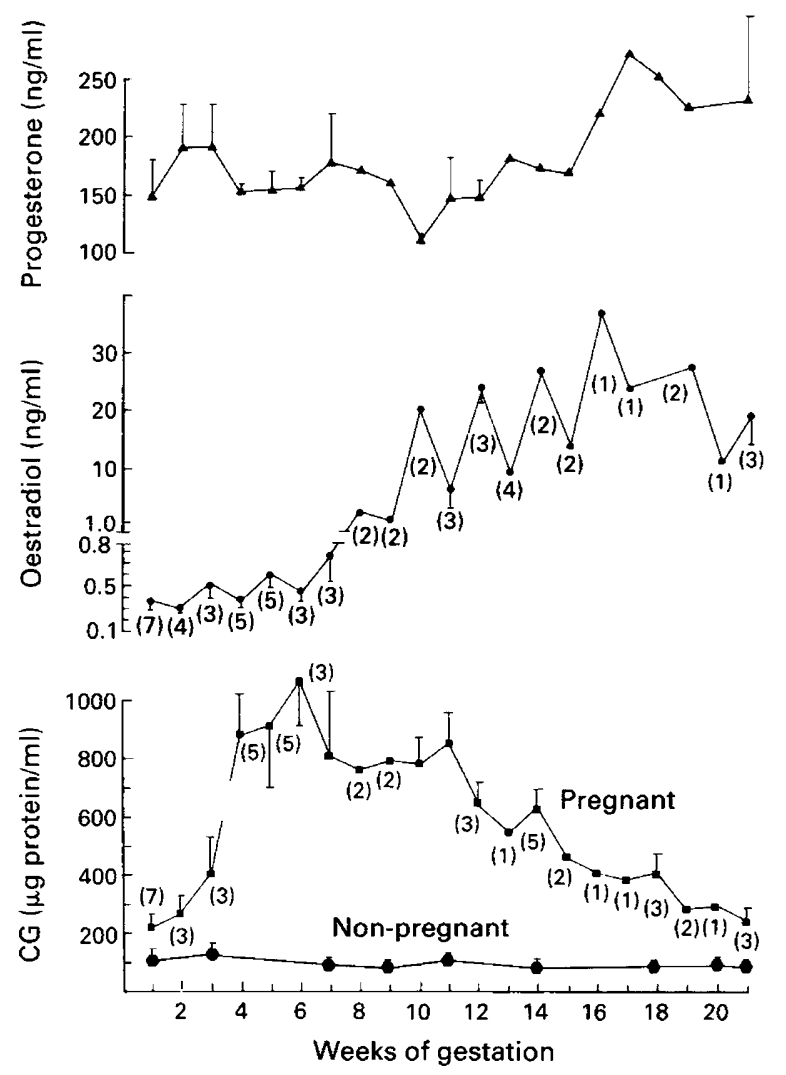

Fig. 3. Circulating serum concentrations (mean \pm s.e.m.) of chorionic gonadotrophin $(\boldsymbol{\square})$, oestradiol $(\boldsymbol{\Theta})$, and progesterone $(\boldsymbol{\Delta})$ during pregnancy in the squirrel monkey. Numbers in parentheses denote number of measurements at each point. Number of measurements for progesterone is the same as for oestradiol. CG concentrations for non-pregnant squirrel monkeys sampled during the same time period are shown in the lowest graph $(\bullet, N=4)$.

The hormone measurements obtained from Group A (early gestation) and Group B (entire gestation period) were combined to construct Fig. 3 which depicts the patterns of secretion for $\mathrm{CG}$, oestradiol and progesterone throughout the gestation period in the squirrel monkey. These patterns can be summarized as follows.

(1) A gradual increase in CG concentrations occurred during the first few weeks of pregnancy, reaching maximum levels at the end of the first third of pregnancy. Concentrations remained elevated until mid-gestation and then began to decrease to non-pregnant values by the end of the gestation period. CG values for early, mid- and late pregnancy were compared by analysis of variance and the differences were significant $(P<0 \cdot 001)$.

(2) Serum oestradiol concentrations ranged between 300 and $600 \mathrm{pg} / \mathrm{ml}$ during the first third of gestation, increasing thereafter to very high levels $(10-35 \mathrm{ng} / \mathrm{ml})$. These differences were also found to be significant by analysis of variance $(P<0.001)$.

(3) Progesterone concentrations remained fairly constant during the first 15 weeks of pregnancy, between 100 and $200 \mathrm{ng} / \mathrm{ml}$.

Table 2 depicts the changes in serum prolactin-like activity which occurred throughout pregnancy in the 5 animals in Group B. There was an increase in prolactin concentrations during pregnancy. After Week 9 the values were greater than those observed in cyclic non-pregnant animals $(5 \cdot 9-16 \mathrm{ng} / \mathrm{ml})$. Prolactin values continued to rise for the remainder of pregnancy and reached 
Table 2. Human prolactin-like activity ( $\mathrm{ng} / \mathrm{ml}$ ) during pregnancy in the squirrel monkey

\begin{tabular}{lccccccc}
\hline & \multicolumn{7}{c}{ Gestation period (weeks) $^{*}$} \\
\cline { 2 - 8 } & $1-3$ & $4-6$ & $7-9$ & $10-12$ & $13-15$ & $16-18$ & $19-21$ \\
\hline No. of & 3 & 5 & 5 & 8 & 5 & 2 & 5 \\
samples & $15 \cdot 9$ & $12 \cdot 2$ & $16 \cdot 1$ & $38 \cdot 2$ & $50 \cdot 3$ & $65 \cdot 8$ & $60 \cdot 4$ \\
Mean & $2 \cdot 8$ & $2 \cdot 8$ & $4 \cdot 4$ & $7 \cdot 6$ & $5 \cdot 9$ & & 3 \\
s.e.m. & 2.0 &
\end{tabular}

*The 21 weeks of gestation were divided into seven 3-week periods.

$P<0.001$ for Weeks 1-7 vs 8-14 vs 15-21 by ANOVA.

maximum levels of over $60 \mathrm{ng} / \mathrm{ml}$ at term. Analysis of variance showed statistically significant differences in prolactin-like activity between the three thirds of pregnancy $(P<0.001)$.

\section{Discussion}

In the present study, the circulating concentrations, patterns, and temporal relationships for CG, oestradiol, progesterone and prolactin are described for the Bolivian squirrel monkey. Although individual differences were observed, a fairly consistent pattern of hormonal secretion was recognized.

The early detection of pregnancy by measurements of CG is more difficult to carry out in New World primates such as the squirrel monkey than in Old World primates and women. Antibodies to squirrel monkey CG are not currently available for the establishment of specific radioimmunoassays. In addition, peak concentrations of CG are reported to be 100 to 1000 times lower in New World primates than in women (Hodgen, 1980). Using several analytical methods, (Hodgen et al., 1978) has shown that, in the squirrel monkey, CG is detectable only from about Day 25 of pregnancy, with peak concentrations occurring at mid-gestation (Day 65-75), then becoming undetectable during the final weeks of pregnancy. In contrast, CG concentrations in women and apes are maximal during the first third of pregnancy and are detectable throughout pregnancy (Hodgen, 1979).

In the present study we established a heterologous radioimmunoassay for measurements of squirrel monkey CG using reagents previously described for the measurement of chorionic gonadotrophins in other primates (Hodgen et al., 1974). The relatively non-specific antiserum used in this assay was able to detect rising levels of $C G$ at about the end of the first month of pregnancy (see Fig. 1). The assay clearly distinguished between elevated concentrations of CG present in pregnant monkeys and the much lower levels (about 25\%) in non-pregnant cyclic animals (Table 1). In Group B, CG measurements over the entire gestation period showed that maximum concentrations of CG are attained between 4 and 11 weeks of gestation (mid-pregnancy) and decline thereafter, reaching low levels during the final weeks of gestation (Fig. 3). These findings are in agreement with other reports on the squirrel monkey (Hodgen et al., 1978; Hodgen, 1980).

The circulating concentrations of oestradiol and progesterone and their temporal relationships during pregnancy have not been previously described for the squirrel monkey. The present study shows a rise in steroid hormone concentrations which parallel the decline in CG levels observed during the second half of pregnancy (Fig. 3). The concentrations of oestradiol showed a slight rise during the first 8 weeks of pregnancy, increasing from about 0.3 to over $1.0 \mathrm{ng} / \mathrm{ml}$ during the last third. Progesterone concentrations were fairly constant during the first 15-16 weeks of pregnancy, fluctuating between 100 and $200 \mathrm{ng} / \mathrm{ml}$ and then rising to maximum levels (over $250 \mathrm{ng} / \mathrm{ml}$ ) before birth. The rise in steroid hormone concentration during the second half of pregnancy coincides with the development of the fetoplacental unit and suggests a placental origin of the steroids, as 
observed in women (Jaffe, 1978) and in other primate species (Hodgen, 1979). It remains to be determined whether placental aromatization of fetal androgens accounts for the rapid rise of circulating oestradiol during the last half of pregnancy in the squirrel monkey as observed in other primates (Buster \& Marshall, 1979; Hearn, 1983).

The results of this study suggest that early pregnancy can be diagnosed in the squirrel monkey by making measurements of serum progesterone concentrations at 3-day intervals. After conception, serum concentrations of progesterone rarely drop below $100 \mathrm{ng} / \mathrm{ml}$, whereas during the breeding season (in cyclic animals) preovulatory levels of progesterone decline to $20 \mathrm{ng} / \mathrm{ml}$ or less and remain there for 2-3 days or more (Diamond et al., 1984). This does not occur in pregnant animals. This observation suggests that 3 consecutive measurements of progesterone, 3 days apart, with values of at least $100 \mathrm{ng} / \mathrm{ml}$, would be diagnostic for pregnancy.

In the present study both oestradiol and progesterone concentrations appeared to decrease during the last 3-4 weeks of pregnancy (Fig. 3), but additional measurement would be required to substantiate this observation. In most species (e.g. sheep, cows, rabbits) the circulating concentrations of progesterone fall in oestrogens rise during the weeks before parturition. A pattern similar to that described for most species has been reported for women (Turnbull et al., 1974); however, others have not been able to confirm these observations and have reported relatively unchanging levels of oestradiol and progesterone during the last 5 weeks of pregnancy (Tulchinsky et al., 1972; Mathur et al., 1980). The pattern is different in pregnant rhesus monkeys in which the concentrations of both steroids increase, slowly reaching a plateau around Day 100 which is maintained until term (Hodgen et al., 1972).

Prolactin-like activity in the squirrel monkey appears to rise progressively after the first third of pregnancy to values $>60 \mathrm{ng} / \mathrm{ml}$ at term (Table 2). This pattern of prolactin secretion is similar to that observed in women (Tyson et al., 1972) and in chimpanzees (Reyes et al., 1975), but differs from observations in the rhesus monkey in which serum prolactin concentrations only begin to rise during the last week of pregnancy (Weiss et al., 1976). The functional significance of the progressive rise in prolactin during pregnancy is probably related to its lactogenic function, and the actual rise is related to the increasing levels of circulating oestrogens (Schenker et al., 1975; Biswas \& Rodeck, 1976).

The actual ranges of circulating steroid concentrations in the pregnant squirrel monkey were $0 \cdot 3-37 \mathrm{ng}$ oestradiol $-17 / \mathrm{ml}$ and $80-370 \mathrm{ng}$ progesterone $/ \mathrm{ml}$ and were in the same range as those reported for pregnant women (Buster \& Marshall, 1979). In contrast, peak concentrations of circulating oestradiol and progesterone in rhesus and cynomolgus monkeys are only $3-4 \%$ and $2-20 \%$ respectively of those observed during the last third of pregnancy in women and squirrel monkeys (Hodgen et al., 1972; Hodgen, 1979). Species differences in circulating concentrations of steroids and their temporal patterns suggest that the hormonal requirements of pregnancy may not be the same for the different primate species.

We thank Dr Hiram Mendenhall for his support and ongoing interest in these studies; $\mathrm{Mr}$ Robert Ricker for excellent technical assistance; Dr Gary D. Hodgen of the N.I.H. for the gonadotrophin reagents; Dr V. Mahesh of The Medical College of Georgia for the progesterone antiserum; Dr K. Wright and Dr D. C. Collins of Emory University for oestradiol antiserum; and Ms Mary Lou Russell for literature research and for typing of the manuscript.

This study was supported by National Institute of Health, Division of Research Resources, Grant No. RR01254.

\section{References}

Biswas, S. \& Rodeck, C.H. (1976) Plasma prolactin levels during pregnancy. Br. J. Obstet. Gynaecol. 83, 683-687.
Buster, J.E. \& Marshall, J.R. (1979) Conception, gamete and ovum transport, implantation, fetal-placental hormones, hormonal preparation for parturition and 
parturition control. In Endocrinology, pp. 1595-1612. Eds L. J. DeGroot, G. F. Cahill, L. Martini, D. H. Nelson, A. I. Winegrad, W. D. O'Dell, J. T. Potts \& E. Steinberger. Grune and Stratton, New York.

Carter, P. (1978) Preparation of ligand-free human serum for radioimmunoassay by absorption on activated charcoal. Clin. Chem. 24, 362-364.

Diamond, E.J., Aksel, S., Hazelton, J.M. \& Abee, C.R. (1984) Seasonal changes of serum concentrations of estradiol and progesterone in Bolivian squirrel monkeys (Saimiri sciureus). Am. J. Primatol. 6, 103-113.

Dukelow, W.R. (1983) The squirrel monkey (Saimiri sciureus). In Reproduction in New World Primates, pp. 149-179. Ed. J. Hearn. MTP Press Ltd, Boston.

Greenwood, F.C. \& Hunter, W.M. (1963) The preparation of ${ }^{131} \mathrm{I}$-labelled human growth hormone of high specific activity. Biochem. J. 89, 114-123.

Hearn, J.P. (1983) The common marmoset (Callithrix jacchus). In Reproduction in New World Primates, pp. 181-215. Ed. J. P. Hearn. MTP Press Ltd, Boston.

Hodgen, G.D. (1979) Primate model for pregnancy hormone secretion in man: fetal, maternal, and placental factors. In Animal Models for Research on Contraception and Fertility. pp. 425-436. Ed. N. J. Alexander, Harper and Row, Hagerstown.

Hodgen, G.D. (1980) Patterns of secretion and antigenic similarities among primate gonadotropins: signifcance in fertility research. In Chorionic Gonadotropin, pp. 53-63. Ed. S. J. Segal. Plenum, New York.

Hodgen, G.D., Dufau, M.L., Catt, K.J. \& Tulner, W.W. (1972) Estrogens, progesterone and chorionic gonadotropin in pregnant rhesus monkeys. Endocrinology 91 , 896-900.

Hodgen, G.D., Tullner, W.W., Vaitukaitis, J.L., Ward, D.N. \& Ross, G.T. (1974) Specific radioimmunoassay of chorionic gonadotropin during implantation in rhesus monkeys. J. clin. Endocr. Metab. 39, 457-464.

Hodgen, G.D., Stolzenbert, S.J., Jones, D.C.L., Hildebrand, D.F. \& Turner, C.K. (1978) Pregnancy diagnosis in squirrel monkeys: hemagglutination test, radioimmunoassay, and bioassay of chorionic gonadotropin. J. med. Primatol. 7, 59-64.

Jaffe, R.B. (1978) The endocrinology of pregnancy. In Reproductive Endocrinology: Physiology, Pathophysiology and Clinical Management, pp. 521-536. Eds S. C. Yen \& R. B. Jaffee. Saunders, Philadelphia.

Kerber, W.T., Conaway, C.H. \& Smith, D.M. (1977) The duration of gestations in the squirrel monkey (Saimiri sciureus). Lab. Anim. Sci. 27, 700-702.
Mathur, R.S., Landgrebe, S. \& Williamson, H.O. (1980) Progesterone, 17-hydroxyprogesterone, estradiol and estriol in late pregnancy and labor. Am. J. Obstet. Gynecol. 136, 25-27.

Nathan, T.S., Rosenblum, L.A., Limson, G. \& Nelson, J.H., Jr (1966) Diagnosis of pregnancy in the squirrel monkey. Anat. Rec. 155, 531-536.

Reyes, F.I., Winter, J.S.D., Faiman, D. \& Hobson, W.C. (1975) Serial serum levels of gonadotropins, prolactin and sex steroids in the nonpregnant and pregnant chimpanzee. Endocrinology 96, 1447-1455.

Schenker, J.G., Ben-David, M. \& Polishuk, W.Z. (1975) Prolactin in normal pregnancy: relationship of maternal, fetal, and amniotic fluid levels. Am. J. Obstet. Gynecol. 123, 834-838.

Stolzenberg, S.J., Jones, D.C.L., Kaplan, J.N., Barth, R.A., Hodgen, G.D. \& Maden, S.M. (1979) Studies with timed-pregnant squirrel monkeys (Saimiri sciureus). J. med. Primatol. 8, 29-38.

Thorell, J.I. \& Johansson, B.G. (1971) Enzymatic iodination of polypeptides with ${ }^{125}$ I to high specific activity. Biochim. Biophys. Acta 251, 363-369.

Tulchinsky, D., Hobel, C.J., Yeager, E. \& Marshall, J.R. (1972) Plasma estrone, estradiol, estriol, progesterone and 17-hydroxyprogesterone in human pregnancy. Am. J. Obstet. Gynecol. 112, 1095-1100.

Turnbull, A.C., Flint, A.P.F., Jeremy, J.Y., Patten, P.T., Keirse, M.J.N.C. \& Anderson, A.B.M. (1974) Significant fall in progesterone and rise in oestradiol levels in human peripheral plasma before onset of labor. Lancet 1, 101-104.

Tyson, J.E., Hwang, P., Guyda, H. \& Friesen, H.G. (1972) Studies of prolactin secretion in human pregnancy. Am. J. Obstet. Gynecol. 113, 14-20.

Weiss, G., Butler, W.R., Hotchkiss, J., Kierschke, D.J. \& Knobil, E. (1976) Periparturitional serum concentrations of prolactin, the gonadotropins, and the gonadal hormones in the rhesus monkey. Proc. Soc. exp. Biol. Med. 151, 113-116.

Wright, K., Collins, D.C. \& Preedy, J.R.K. (1973) Comparative specificity of antisera raised against estrone, estradiol-17 $\beta$ and estriol using 6-O-carboxymethyloxime bovine serum albumin derivatives. Steroids 21, 755-769.

Wright, K., Collins, D.C. \& Preedy, J.R.K. (1978) The use of specific radioimmunoassays to determine the renal clearance rates of estrone and $17 \beta$-estradiol during the menstrual cycle. J. clin. Endocr. Metab. 47, 1084-1091.

Received 7 July 1986 